\title{
Therapeutic effect of gastrografin and predictors of operative intervention in patients with adhesive small bowel obstruction: A randomized controlled study
}

\author{
Hamid Reza Khorshidi', Parviz Majidi ${ }^{1}$, Azar Pirdehghan ${ }^{2}$ \\ ${ }^{1}$ Department of General Surgery, Hamadan University of Medical Sciences, Hamadan, Iran \\ ${ }^{2}$ Department of Community and Preventive Medicine, Hamadan University of Medical Sciences, Hamadan, Iran
}

\begin{abstract}
Objective: The study aimed to investigate the therapeutic effect of gastrografin for the conservative treatment of patients with adhesive small bowel obstruction (ASBO) and to identify the predictors of failure of conservative treatment in these patients.

Material and Methods: A randomized controlled trial was conducted on 52 patients with the diagnosis of ASBO in $2016.100 \mathrm{~mL}$ of Gastrografin and $100 \mathrm{~mL}$ of $0.9 \%$ saline solution were gavaged through the nasogastric tube in the case $(n=26)$ and control $(n=26)$ groups, respectively. Patients in the case group were subjected to plain abdominal X-Rays at 12, 24 and 48 hours after administration of gastrografin.

Results: Fifty-two patients with a mean age of $57.6 \pm 11.4$ years (range 37-81), including 34 (65.4\%) males were enrolled into the study. The number of patients who were successfully conservatively treated in the case group was $21(80.8 \%)$, which was significantly higher than $13(50 \%)$ in the control group $(p=0.04)$. Among these patients, mean hospital stay in the case group was $37.2 \pm 5.5$ hours (range 28-46), which was significantly shorter than $45.8 \pm$ 9.2 hours (range $36-61)$ in the control group $(p=0.004)$. In multivariate analysis, more than one previous laparotomy was the only predictor of failure of conservative treatment $(p<0.001)$.
\end{abstract}

Conclusion: Gastrografin may be associated with improvement of patients with ASBO. Lower number of previous laparotomies may be a predictor of successful conservative treatment of these patients.

Keywords: Gastrografin, adhesive small bowel obstruction, predictors

Cite this article as: Khorshidi HR, Majidi P, Pirdehghan A. Therapeutic effect of gastrografin and predictors of operative intervention in patients with adhesive small bowel obstruction: A randomized controlled study. Turk J Surg 2019; 35 (2): 131-135

Corresponding Author Hamid Reza Khorshidi E-mail: khorshidi@umsha.ac.ir

Received: 01.06 .2018

Accepted: 28.08 .2018

Available Online Date: 13.06 .2019

( C) Copyright 2019 by Turkish Surgical Society Available online at www.turkjsurg.com

DOI: $10.5578 /$ turkjsurg.4237

\section{INTRODUCTION}

Small bowel obstruction is one of the major causes of hospitalization which imposes significant health and economic burden (1). Adhesive small bowel obstruction (ASBO) due to prior laparotomy is the most common cause of small bowel obstruction which can be treated operatively or conservatively (2). Emergent operative intervention is performed in patients with ASBO with signs of strangulation or peritonitis which is technically difficult and is associated with bowel injuries and high postoperative morbidity $(3,4)$. Conservative treatment including nasogastric tube decompression, intravenous fluid replacement and close monitoring may result in resolution of obstruction in most of the patients with $\mathrm{ASBO}$; however, who fails conservative treatment should undergo operation (5).

Recently, utilization of water-soluble contrast agents mainly gastrografin has become more popular for the diagnosis and treatment of patients with ASBO (6). However, there is no consensus on the therapeutic effect and protocol of using these agents for conservative management of patients with ASBO. Several studies suggest that water-soluble contrast agents may be used for the diagnosis of resolution of obstruction, predicting the need for surgical intervention and simultaneously, can be used for conservative treatment of ASBO by stimulating the bowel movement due to their hyperosmolar effect and water movement into the small bowel lumen (7-11). Contrary, there are some studies showing that using water-soluble contrast agents has no therapeutic effect as a conservative treatment in patients with $\operatorname{ASBO}(12,13)$. 
The present study aimed to investigate the therapeutic effect of gastrografin for the conservative treatment of patients with ASBO and to identify the predictors of failure of conservative treatment in these patients in our center.

\section{MATERIAL and METHODS}

\section{Patient Selection}

A randomized controlled trial was conducted on patients with the diagnosis of ASBO in 2016. Inclusion criteria were the patients with history of prior laparotomy presenting with obstruction related symptoms including abdominal distention and pain, vomiting, and constipation and radiological findings including air-fluid levels and small bowel distention in plain abdominal X-Ray. Patients with history of prior laparotomy within a month before the development of symptoms, signs and symptoms of strangulation or peritonitis including abdominal guarding tenderness or rebound tenderness, fever and leukocytosis of more than 10000, sepsis, septic shock, pregnancy, history of malignancy, allergy to iodine, incarcerated incisional or inguinal hernia were excluded from the study. Fifty-two patients were enrolled into the study and were randomly assigned to the case $(n=26)$ and control $(n=26)$ groups by simple randomization method using random numbers generated through computer. The CONSORT flow diagram showing the patients selection process is depicted in Figure 1.

\section{Study Protocol}

A nasogastric tube was inserted for each patient in the emergency department and stomach contents were drained for two hours. Then $100 \mathrm{~mL}$ of oral gastrografin solution (Bayer Schering Pharma, Germany) and $100 \mathrm{~mL}$ of $0.9 \%$ saline solution were gavaged through the nasogastric tube in the case and control groups, respectively. The nasogastric tube was clamped for two hours. Following clamping, all patients were continuously monitored and visited by a same surgeon. Patients in the case group were subjected to plain abdominal X-Rays at 12,24 and 48 hours after administration of oral contrast media.

In patients in whom the oral contrast was detected in the cecum in each plain abdominal X-Ray, the nasogastric tube was removed and oral feeding with liquids was started. Conservative treatment was considered successful when improvement of patient symptoms with passage of gas or feces was occurred during the 48 hours of administration of contrast media or saline. Otherwise, conservative management was considered failed when strangulation or peritonitis was suspected during 48 hours of gavage administration, the contrast media was not reached to the cecum or no flatus or bowel movement occurred after 48 hours of gavage administration. In such cases, conservative treatment was terminated and emergent operative intervention including adhesiolysis or bowel resection through a midline incision was undertaken by the same surgeon.

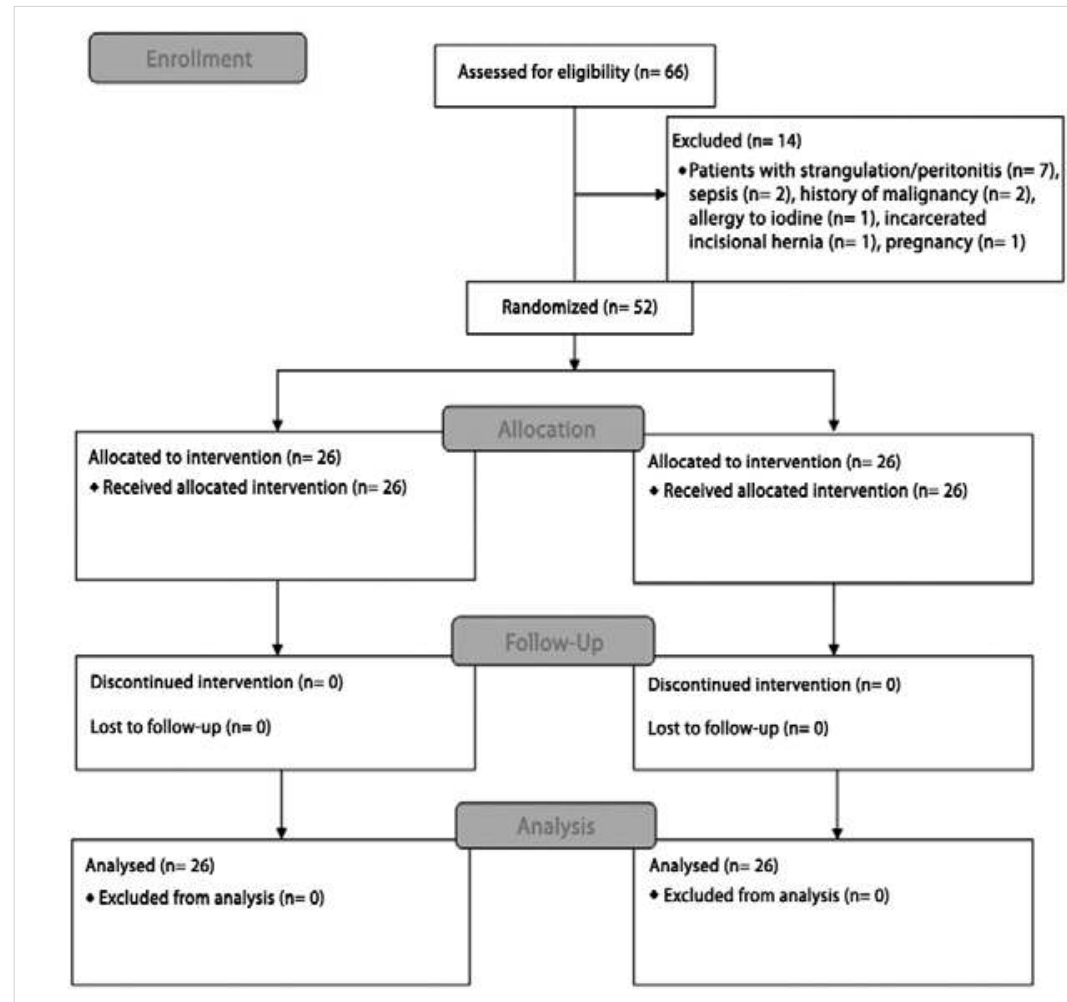

Figure 1. CONSORT flow diagram of the process of patient selection. 


\section{Ethics}

This study was conducted after obtaining the approval of Ethics Committee of Hamadan University of Medical Sciences. Patients were enrolled into the study when the aims and objectives of the study were explained and a written informed consent was taken from each patient. The study has been registered in the Iranian Registry of Clinical Trials with reference number of IRCT201704259014N160.

\section{Statistical Analyses}

Data were analyzed using the SPSS statistical software (IBM SPSS Statistics for Windows, Version 23.0, IBM Corp., Armonk, NY, USA). Qualitative and quantitative data were compared using Chisquare and independent two sample-t tests, respectively. Univariate analysis and multivariate analysis using logistic regression were performed to assess predictors of failure of conservative treatment. $P$ value less than 0.05 was considered significant.

\section{RESULTS}

Fifty-two patients with a mean age of $57.6 \pm 11.4$ years (range 37 - 81), including 34 (65.4\%) males were enrolled into the study. As shown in Table 1, there was no significant difference between age, gender, indication and compartment of previous laparotomy, and number of previous laparotomies in the case and control groups. Duration of symptoms before admission were 33.2 \pm 18.6 hours (range 5.8-91.3) and $30.8 \pm 17$ hours (range 9-75.3) in the case and control groups, respectively, with no significant difference $(p=0.63)$

The number of patients who were successfully conservatively treated in the case group was 21 (80.8\%), which was significantly higher than $13(50 \%)$ in the control group ( $p=0.04)$. Among these patients, mean hospital stay in the case group was $37.2 \pm$ 5.5 hours (range 28-46), which was significantly shorter than 45.8 \pm 9.2 hours (range 36-61) in the control group $(p=0.004)$.

In univariate analysis, longer duration of symptoms before admission and more than one previous laparotomy were the significant predictors of failure of conservative treatment in all patients with ASBO ( $p=0.024$ and $p=0.001$, respectively). However, in multivariate analysis, more than one previous laparotomy was the only predictor of failure of conservative treatment $(p<0.001)$

\section{DISCUSSION}

Our results showed that conservative therapy using Gastrografin was associated with significant improvement and substantial reduction in hospital stay of the patients with ASBO using a cut-off point of 48 hours after administration of gastrografin or saline for making decision to operate the patients with persistent symptoms. Gastrografin is an extremely hypertonic water-soluble iodinated contrast agent having an osmolality of $1900 \mathrm{mOsm} / \mathrm{L}$, which is six

\begin{tabular}{|c|c|c|c|}
\hline & $\begin{array}{l}\text { Case group } \\
(n=26)\end{array}$ & $\begin{array}{l}\text { Control group } \\
(n=26)\end{array}$ & $\mathbf{p}$ \\
\hline Gender, males \% & 61.5 & 69.2 & 0.77 \\
\hline Age (yrs/old) & $\begin{array}{c}56.6 \pm 10.7^{*} \\
\text { (range 38-75) }\end{array}$ & $\begin{array}{c}58.6 \pm 12.2 \\
\text { (range 37-81) }\end{array}$ & 0.52 \\
\hline \multicolumn{4}{|l|}{ Indication of previous abdominal operation } \\
\hline Appendicitis & 13 & 10 & 0.58 \\
\hline Perforated peptic ulcer & 5 & 6 & 1 \\
\hline Volvulus & 4 & 5 & 1 \\
\hline Cholecystitis & 2 & 3 & 1 \\
\hline Hernia & 0 & 1 & 1 \\
\hline Gynecologic & 2 & 1 & 1 \\
\hline Number of previous abdominal operations & & & 0.7 \\
\hline 1 & 23 & 21 & \\
\hline 2 & 3 & 5 & \\
\hline Previous operation for ASBO & 2 & 4 & 0.64 \\
\hline \multicolumn{4}{|l|}{ Abdominal compartment of previous operation } \\
\hline Infracolic & 13 & 10 & 0.58 \\
\hline Supracolic & 7 & 8 & 1 \\
\hline Both & 6 & 8 & 0.75 \\
\hline \multicolumn{4}{|l|}{${ }^{*}$ Mean \pm standard deviation. } \\
\hline
\end{tabular}


times that of plasma. Following administration of Gastrografin, the pressure gradient is increased across the lumen of the small bowel which results in absorption of fluid into the lumen of the intestine, decrease of bowel wall edema, increase of peristalsis and subsequent resolution of small bowel obstruction (10).

Therapeutic effect of water-soluble contrast agents have been investigated in many studies. In a randomized controlled trial by Haule et al., 22 out of 25 (88\%) patients with ASBO have been treated successfully with gastrografin compared to 16 out of 25 (64\%) patients undergoing standard conservative treatment with no significant difference. However, in this study, the use of gastrografin was attributed to a significant reduction in length of hospital stay and time for resolution of obstruction. The authors used a cut-off point of 5 days after randomization for deciding to operate (14). Another randomized controlled trial by Rahmani et al. on 84 patients with ASBO has shown that the need for surgical intervention in contrast to length of hospital stay was not significantly reduced in patients who were treated with gastrografin compared to the control ones using a cut-off point of 4 days (15). In a recent multicenter randomized controlled trial by Scotté et al., administration of gastrografin in 121 patients with ASBO has not been found to be associated with reduction in the rate of operation or length of hospital stay using cut-off point of 48 hours waiting compared to 121 patients in the control group (24\% vs. $20 \%$ and 3.8 vs. 3.5 days, respectively) (11). On the other hand, similar to our data, in a multicenter observational study by Zielinski et al. a significant reduction in rates of surgical intervention and hospital stay has been reported using cut-off point 3-5 days waiting in 173 patients treated with gastrografin for ASBO compared to 143 patients conservatively managed without gastrografin (20.8\% vs. $44.1 \%$ and 4 vs. 5 days, respectively) (6). Also, a recent systematic review and meta-analysis by Ceresoli et al., have supported our findings, showing that administration of water soluble contrast agents resulted in a significant reduction of need for surgical intervention and length of hospital stay (16). The observed discrepancy through various studies may be due to different study designs, sample sizes and treatment protocols including using different cut-off points for deciding to operate.

In our study, more than one previous laparotomy was the only predictor of failure of conservative treatment of ASBO. Available data vary through studies about predictors of failure of conservative treatment of ASBO. Similar to ours, in a study by Bueno-lledo et al., age and number of previous laparotomies are the predictors of failure of conservative treatment of ASBO (17). A study by Komatsu et al. have shown that in univariate analysis for predictors of failure of conservative treatment of ASBO, age and number of previous laparotomies are significant however, in multivariate analysis the number of previous laparotomies is not significant (18). In contrast to our data, in a study by Miquel et al., age over 75 years was the predictor of failure of conservative treatment of
ASBO after colorectal resection surgery while number of previous laparotomies or duration of symptoms before admission were not the predictors (19). Besides, Zielinski et al. 2010 concluded that either the age or number of previous laparotomies were not predictors of failure of conservative treatment of ASBO (20).

\section{CONCLUSION}

The present study showed that administration of gastrografin may be associated with improvement of patients with ASBO, and lower number of previous laparotomies may be a predictor of successful conservative treatment of these patients.

Ethics Committee Approval: Ethics committee approval was received for this study from the Ethics Committee of Hamadan University of Medical Sciences.

Informed Consent: Written informed consent was obtained from patients who participated in this study.

Peer-review: Externally peer-reviewed.

Author Contributions: Consept - H.R.K., P.M.; Design - H.R.K., P.M., A.P.; Supervision - H.R.K.; Materials - P.M.; Data Collection and/or Processing - P.M., A.P.; Analysis and Interpretation - H.R.K., P.M.; Literature Search - P.M., A.P.; Writing Manuscript - P.M., A.P.; Critical Reviews - H.R.K.

Conflict of Interest: The authors have no conflicts of interest to declare.

Financial Disclosure: The authors declared that this study has received no financial support.

\section{REFERENCES}

1. Miller G, Boman J, Shrier I, Gordon PH. Etiology of small bowel obstruction. Am J Surg 2000; 180: 33-6. [CrossRef]

2. Catena F, Di Saverio S, Kelly MD, Biff WL, Ansaloni L, Mandala V, et al. Bologna Guidelines for Diagnosis and Management of Adhesive Small Bowel Obstruction (ASBO): 2010 Evidence-Based Guidelines of the World Society of Emergency Surgery. World J Emerg Surg 2011; 6:5. [CrossRef]

3. Ellis H, Moran BJ, Thompson JN, Parker MC, Wilson MS, Menzies D, et al. Adhesion-related hospital readmissions after abdominal and pelvic surgery: a retrospective cohort study. Lancet 1999; 353: 1476-80. [CrossRef]

4. Van Der Krabben AA, Dijkstra FR, Nieuwenhuijzen M, Reijnen MM, Schaapveld M, Van Goor H. Morbidity and mortality of inadvertent enterotomy during adhesiotomy. Br J Surg 2000; 87: 467-71. [CrossRef]

5. Di Saverio S, Coccolini F, Galati M, Smerieri N, Biff WL, Ansaloni L, et al. Bologna guidelines for diagnosis and management of adhesive small bowel obstruction (ASBO): 2013 update of the evidence-based guidelines from the world society of emergency surgery ASBO working group. World J Emerg Surg 2013; 8: 42. [CrossRef]

6. Zielinski MD, Haddad NN, Cullinane DC, Inaba K, Yeh DD, Wydo S, et al. Multi-institutional, prospective, observational study comparing the Gastrografin challenge versus standard treatment in adhesive small bowel obstruction. J Trauma Acute Care Surg 2017; 83: 47-54. [CrossRef]

7. Abbas SM, Bissett IP, Parry BR. Meta-analysis of oral water-soluble contrast agent in the management of adhesive small bowel obstruction. Br J Surg 2007; 94: 404-11. [CrossRef]

8. Biondo S, Pares D, Mora L, Marti Rague J, Kreisler E, Jaurrieta E. Randomized clinical study of Gastrografin administration in patients with adhesive small bowel obstruction. Br J Surg 2003; 90: 542-6. [CrossRef] 
9. Burge J, Abbas SM, Roadley G, Donald J, Connolly A, Bissett IP, et al. Randomized controlled trial of Gastrografin in adhesive small bowel obstruction. ANZ J Surg 2005; 75: 672-4. [CrossRef]

10. Choi HK, Chu KW, Law WL. Therapeutic value of gastrografin in adhesive small bowel obstruction after unsuccessful conservative treatment: a prospective randomized trial. Ann Surg 2002; 236: 1-6. [CrossRef]

11. Scotte M, Mauvais F, Bubenheim M, Cosse C, Suaud L, Savoye-Collet $C$, et al. Use of water-soluble contrast medium (gastrografin) does not decrease the need for operative intervention nor the duration of hospital stay in uncomplicated acute adhesive small bowel obstruction? A multicenter, randomized, clinical trial (Adhesive Small Bowel Obstruction Study) and systematic review. Surgery 2017; 161: 1315-25. [CrossRef]

12. Feigin E, Seror D, Szold A, Carmon M, Allweis TM, Nissan A, et al. Watersoluble contrast material has no therapeutic effect on postoperative small-bowel obstruction: results of a prospective, randomized clinical trial. Am J Surg 1996; 171:227-9. [CrossRef]

13. Fevang BT, Jensen D, Fevang J, Sondenaa K, Ovrebo K, Rokke O, et al. Upper gastrointestinal contrast study in the management of small bowel obstruction--a prospective randomised study. Eur J Surg 2000; 166: 39-43. [CrossRef]

14. Haule C, Ongom PA, Kimuli T. Efficacy of Gastrografin ${ }^{\oplus}$ Compared with Standard Conservative Treatment in Management of Adhesive Small Bowel Obstruction at Mulago National Referral Hospital. J Clin Trials 2013; 3. [CrossRef]
15. Rahmani N, Mohammadpour RA, Khoshnood P, Ahmadi A, Assadpour S. Prospective evaluation of oral gastrografin ${ }^{\circledast}$ in the management of postoperative adhesive small bowel obstruction. Indian J Surg 2013; 75: 195-9. [CrossRef]

16. Ceresoli M, Coccolini F, Montori G, Sartelli M, Catena F, Ansaloni L. Water-soluble contrast agent in adhesive small bowel obstruction: the game is still on. Surgery 2017; 162: 199-200. [CrossRef]

17. Bueno-Lledo J, Barber S, Vaque J, Frasson M, Garcia-Granero E, JuanBurqueno M. Adhesive small bowel obstruction: predictive factors of lack of response in conservative management with gastrografin. Dig Surg 2016; 33: 26-32. [CrossRef]

18. Komatsu I, Tokuda Y, Shimada G, Jacobs JL, Onodera H. Development of a simple model for predicting need for surgery in patients who initially undergo conservative management for adhesive small bowel obstruction. Am J Surg 2010; 200: 215-23. [CrossRef]

19. Miquel J, Biondo S, Kreisler E, Uribe C, Trenti L. Failure of conservative treatment with Gastrografin ${ }^{\circledR}$ for adhesive small bowel obstruction after colorectal surgery. Int J Colorectal Dis 2017; 32: 1051-5. [CrossRef]

20. Zielinski MD, Eiken PW, Bannon MP, Heller SF, Lohse CM, Huebner M, et al. Small bowel obstruction-who needs an operation? A multivariate prediction model. World J Surg 2010; 34: 910-9. [CrossRef]

\title{
ORIJINAL ÇALIŞMA-ÖZET
}

Turk J Surg 2019; 35 (2): 131-135

\section{Adheziv ince bağırsak obstrüksiyonu olan hastalarda gastrografinin terapötik etkisi ve operatif girişim öngörücüleri: Randomize kontrollü çalışma}

\author{
Hamid Reza Khorshidi ${ }^{1}$, Parviz Majidi ${ }^{1}$, Azar Pirdehghan ${ }^{2}$ \\ 1 Hamadan Tıp Bilimleri Üniversitesi, Genel Cerrahi Anabilim Dalı, Hamadan, Iran \\ 2 Hamadan Tıp Bilimleri Üniversitesi, Topluluk ve Önleyici Tıp Anabilim Dalı, Hamadan, İran
}

\section{ÖZET}

Giriş ve Amaç: Bu çalışmanın amacı, adheziv ince bağırsak obstrüksiyonu (AlBO) olan hastaların konservatif tedavisinde gastrografinin terapötik etkisini araştırmak ve bu hastalarda konservatif tedavinin başarısızlık öngörücülerini belirlemekti.

Gereç ve Yöntem: 2016 yılında AlBO tanısı almış olan 52 hasta üzerinde randomize kontrollü bir çalışma yürütüldü. Olgu $(n=26)$ ve kontrol $(n=26)$ gruplarında ardışık olarak $100 \mathrm{~mL}$ gastrografin ve $100 \mathrm{~mL} \% 0,9^{\prime}$ luk salin solüsyon nazogastrik tüp aracılığıyla verildi. Olgu grubundaki hastalar, gastrografin alımını takip eden 12, 24 ve 48. saatlerde direkt karın grafisi incelemesine tabi tutuldu.

Bulgular: Otuz dördü $(\% 65,4)$ erkek olmak üzere toplam 52 hastanın ortalama yaşı 57,6 $\pm 11,4$ yıl (aralık: 37-81) idi. Olgu grubunda başarılı bir şekilde konservatif olarak tedavi edilen hasta sayısı $21(\% 80,8)$ idi ve bu sayı control grubundaki 13 (\%50) hastadan anlamlı derecede yüksekt $(p=0,04)$. Bu hastaların içerisinde olgu grubunun ortalama hastanede kalış süresi 37,2 $\pm 5,5$ saat (aralık: 28-46) olarak bulundu ve bu kontrol grubunun ortalama hastanede kalış süresinden $[45,8 \pm 9,2$ saat (aralık 36-61)] anlamlı derecede daha kısaydı ( $p=0,004)$. Çok değişkenli analizde, konservatif tedavinin başarısızlık öngörücüsü önceden geçirilmiş birden fazla laparotomi olarak bulundu $(p<0,001)$.

Sonuç: Gastrografin, AiBO'lu hastalarda iyileşme ile ilişkili olabilir. Daha az sayıda önceden geçirilmiş laparotomi başarılı konservatif tedavinin öngörüsü olabilir.

Anahtar Kelimeler: Gastrografin, adheziv ince bağırsak obstrüksiyonu, öngörücüler

Doi: $10.5578 /$ turkjsurg.4237 